\title{
Review of Mike Davis (2020). The Monster Enters: COVID 19, Avian Flu, and the Plagues of Capitalism
}

\section{New York and London: OR Books. 205 pp. ISBN 9781682193037 (Paperback)}

\author{
Derek R. Ford ${ }^{1}$ \\ Published online: 14 August 2020 \\ (C) Springer Nature Switzerland AG 2020
}

\section{Introduction}

Mike Davis' The Monster Enters: COVID 19, Avian Flu, and the Plagues of Capitalism (2020) is a revised edition of his 2005 book, The Monster at Our Door (Davis 2005), which was written during and about the Avian Flu (H5N1) outbreak. A particularly pathogenic strain of $\mathrm{H} 5 \mathrm{~N} 1$ virus was identified in chickens and turkeys in 1959 in Scotland and England, respectively, but the virus jumped to humans in 1997 and beginning around 2003 spread vociferously across much of the globe until fading in 2009, although not disappearing. Davis documents the different outbreaks and pathways of H5N1, contextualizing them in relation to other influenzas and SARS, to identify some of the structural geopolitical, social, and economic conditions of their emergence and proliferation and to tease out some of the factors that animate the hyphen between these conditions and the biological. In particular, Davis focuses on the Livestock Revolution, ongoing industrialization, urbanization, and the absence of both intra- and inter-state coordination and planning in the face of intensifying globalization, all of which owe in many ways to the capitalist mode of production.

\section{Structures of the H5N1 Pandemic}

The scale and severity of the H5N1 virus, Davis (2020: 52) says, was 'a destiny... that we have largely forced upon influenza' through 'human-induced environmental shocks - overseas tourism, wetland destruction, a corporate "Livestock Revolution," and Third World urbanization with the attendant

Derek R. Ford

derekford@depauw.edu

1 DePauw University, Greencastle, IN 46135, USA 
growth of megaslums.' The suffering caused by pandemics is, in turn, forced upon people poverty policies of underdevelopment, disinvestment, and dispossession. The story mostly begins in the 1980s with the Livestock Revolution, the large-scale global restructuring of meat production through which massive agrobusinesses displaced subsistence-based and small-scale fishing, hunting, and animal husbandry. Many of the latter were driven out of business as capital increasingly dominated meat production and distribution. Others became contract farmers for agrobusiness, cogs in a vertically integrated global production system whose fates are tied ever more tightly to the fluctuations of the global capitalist marketplace.

With more and more animals concentrated in smaller spaces, weak worker protections in the way of safety and health, the conditions for intra- and interspecies viral transmission, and transformation heighten. The larger the scale of production, the wider the radius of distribution, and the faster the overall circulation process takes shape. The densification of animal commodity production was accompanied by a similar densification of people in urban centers. Moreover, massive deforestation brings humans and animals into contact and removes habitats from animals, which makes them easier to kill and sell. Coupled with inadequate public health systems from state divestment and colonial policies and increasing insecurity and poverty, we have some of the key ingredients for a devastating pandemic to take hold.

Then there are the forces that prevent an effective, efficient, and rapid response, including preparatory measures. Under capitalism, 'products that actually cure or prevent disease, like vaccines and antibiotics, are less profitable, so infectious disease has largely become an orphan market' (Davis 2020: 153). In fact, a worldwide analysis showed that the collective revenue from every single vaccine is less 'than Pfizer's income from a single anticholesterol medication' (154).

The profit motive prevents adequate research and development in the study of and preparation for pandemics because there is no immediately realizable exchange value, let alone a guarantee that there will be a market for them at all.

The relationship between oppression and exploitation on the one hand, and viral spread on the other, does not just hold for the differing impacts of pandemics; it holds too for the attention governments give to them. So long as it is the working class and oppressed peoples of the world who are suffering, there is no swift response and no international mobilization to respond. Davis notes that medical research focuses on 'health issues with broad electoral resonance' (144). Thus, the US government completely ignored the AIDS pandemic, while it funneled resources into research into 'cancer and heart disease' (144). This is in part what explains the extent to which the current novel coronavirus structures so many aspects of so many of our lives. While its impacts are organized along lines of nation, race, ability, and class, it is spread and mortality do not totally discriminate. Still, Davis notes that 'immunologically there are two distinct humanities.' Among the rich, it is 'only the elderly and chronically ill' who are 'sacrificed to Covid-19,' while for the poor, 'where malnutrition, disease, and contaminated water compromise the immune systems of people of all ages and respiratory ailments are legion, the carnage is likely to become more widespread and indifferent to demography' (36). 


\section{Structures of the Current Pandemic}

The explicit consideration of the COVID-19 pandemic comes in the book's new introduction, where Davis takes readers through a brief and meandering journey through the early months of the pandemic. The original manuscript deepens our appreciation for the radical divergence between the consensus within the medical and scientific community that the US is woefully ill prepared for a pandemic and the absolute non-response of the government. Even worse, those few systems set in place to prepare were systematically dismantled over the last few administrations. It is not just Trump. Davis notes, for example, that the Obama administration depleted the government's 105 million N-95 respirator reserves to just 5 million during the 2009 H1N1 pandemic and never replenished the stockpile because 'a better and cheaper solution was [allegedly] to help the private sector develop the production capacity to meet surging demand in a pandemic crisis' (19). Beginning with Bush, pandemic response was largely organized in the 'War on Terror' framework, which Obama continued by creating a Directorate of Global Health Security and Biodefense and locating it as part of the National Security Council.

If Bush militarized pandemic response, Obama privatized it, and Trump accelerated both. Davis writes that the Trump administration failed to prepare and respond to the pandemic in five ways: (1) a lack of organizational leadership and continuity between administrations; (2) the Center for Disease Control's decision to refuse the Covid-19 test kit produced for the World Health Organization in Germany and to instead make their own (which failed); (3) the delayed implementation of social distancing measures (which are themselves delayed responses); (4) the lack of emergency supplies and reluctance to use the Defense Production Act to create the supplies; and (5) the outsourcing of vaccine development to Wellcome Trust, a Non-Governmental Organization project of the Gates Foundation and the Norwegian, German, and Japanese governments.

What is refreshing is the lack of superficial attacks on Trump and his administration. What is frustrating is the confusing - and at times deceitful - geopolitical analysis provided as well as the overall absence of any optimism or potential solutions. While Davis singles out China and Cuba as 'the only countries currently rising to the challenge of providing significant medical aid and expertise to poorer nations' (42), he elsewhere calls China's relationship with Africa 'quasi-imperialist' (38) with, of course, absolutely no explanation. He correctly calls out the Western anti-Chinese propaganda, identifying how it 'veered between discordant stereotypes' where, early on, 'Wuhan local leaders conformed to the image of a corrupt bureaucracy with wooden legs' to later be replaced by the presentation of China as 'a quasi-totalitarian surveillance state' (41). Davis gives China credit for their response but draws a false dichotomy between 'the state' and 'the people' before undermining any such dichotomy. Davis says 'the Communist Party's pervasive presence in daily life - 90.6 million members organized into thousands of workplace and neighborhood committees - was a decisive factor in the total mobilization against Covid,' but then tell us that this only shows 'the critical importance of grassroots organization and preparedness, not the necessity of a police state' (43). The Chinese Communist Party, of course, with its almost 100 million members, leads the state. For precisely this reason, it was able to mobilize and coordinate these grassroots organizations. The designation of "police 
state' is backed up only by a few breathless reassertions of dubious claims by antiChinese forces and only works to reinforce Trump and the Pentagon's war drive against the country and its people.

If one is looking for hope in all of this, they will not find much (if any) in the book. It is all doom and gloom. We can infer what Davis thinks we should do, but only on the most basic and elementary levels. If capitalist production is bad, what else should we organize for? If the elimination of barriers between animals and humans is bad, should we erect new barriers? How do we address megaslums, insecurity, poverty, the profit motive's domination in vaccine, and medical research and development? There is no dialectical investigation into the ways the terror of the pandemic has ignited spontaneous projects of solidarity, sharing, and caring, many of which have been organized and continue to be sustained. The pandemic brings the contradictions of capitalism, imperialism, racism, and ableism into sharp relief, but the potential for resistance does not only lie there. It is also to be found in the heroic efforts of people organizing - through spontaneous networks, established and emerging organizations and coalitions, as well as parties and, yes, states. But if you are looking for some useful journalistic accounting of previous pandemics, this book will do the trick.

\section{Reference}

Davis, M. (2020). The monster enters: COVID 19, avian flu, and the plagues of capitalism. New York and London: OR Books.

Davis, M. (2005). The monster at our door: The global threat of the Avian Flu. New York: Owl Books. 